\title{
On-Farm Evaluation of Beans Varieties for Adaptation and Adoption in Kigoma Region in Tanzania
}

\author{
Tulole Lugendo Bucheyeki ${ }^{1,2}$ and Tuaeli Emil Mmbaga ${ }^{3}$ \\ ${ }^{1}$ University of KwaZulu-Natal, Private Bag X01, Scottsville 3209, South Africa \\ ${ }^{2}$ Tumbi Agricultural Research and Development Institute, P.O. Box 306, Tabora, Tanzania \\ ${ }^{3}$ Selian Agricultural Research and Development Institute, P.O. Box 6024, Arusha, Tanzania \\ Correspondence should be addressed to Tulole Lugendo Bucheyeki; tlbucheyeki@yahoo.co.uk
}

Received 4 March 2013; Accepted 17 April 2013

Academic Editors: A. Berville, G. M. Dal Bello, and M. Ruiz

Copyright (C) 2013 T. L. Bucheyeki and T. E. Mmbaga. This is an open access article distributed under the Creative Commons Attribution License, which permits unrestricted use, distribution, and reproduction in any medium, provided the original work is properly cited.

\begin{abstract}
On-farm beans research was carried out in Kigoma region, Tanzania. Objectives were to evaluate beans varieties for yield under farmers' management conditions and to assess farmers' preferences on beans varieties. Nine farmers from three villages with three farmers per village participated in beans trials. A randomized complete block design with five plots per replications was used to evaluate five bean varieties: Lyamungo 90, Jesca, Uyole 94, Kablanketi, and Kigoma yellow (control). Beans were planted on a $10 \mathrm{~m} \times 2.5 \mathrm{~m}$ plot at a spacing of $50 \mathrm{~cm} \times 20 \mathrm{~cm}$. Data was subjected to analysis using ANOVA table in GenStat statistical computer software. Three villages $\times$ three seasons resulted in nine environments which were used for stability analysis. Farmers developed their criterion to assess the performance and acceptability of beans varieties. Lyamungo 90 and Jesca ranked high and outyielded other varieties with an average yield of 1430.00 and $1325.67 \mathrm{~kg} \mathrm{ha}^{-1}$, respectively. Genotypes sum of squares accounted for the most of the variability $(89.12 \%)$. Introduction of high yielding bean varieties with the desired farmers' traits is expected to revamp beans production and contribute to the improved food security in Tanzania.
\end{abstract}

\section{Introduction}

Common bean (Phaseolus vulgaris L.) is an important herbaceous annual grain legume in the world chiefly grown as a cheap source of protein among majority of Sub-Saharan African people [1].

Farmers frequently use it as a vital component in crop rotation for its ability to fix nitrogen $[2,3]$. According to FAOSTAT [4] estimate for the year 2006, world beans production was $1235 \mathrm{~kg} \mathrm{ha}^{-1}$ while that of Africa was $799 \mathrm{~kg} \mathrm{ha}^{-1}$. The average beans yield per annum in many African countries is always lower than that of the world. Lack of improved varieties associated with edaphic and biotic factors has been cited as one of the primary sources of lower beans production [5]. In Tanzania, common bean is an important food and cash crop which is mostly grown by small-holder farmers [6]. However, common bean production in Tanzania is low and does not meet the increasing demand. The average yield is $741 \mathrm{~kg} \mathrm{ha}^{-1}$ which is lower than that found in the developed countries [4]. The low beans yield is mostly contributed by the use of unimproved varieties. Farmers use the locally available varieties with low yield potential. The result is low yield per area and reduced beans production (Figure 1).

In addition to the lack of improved varieties and high seed demand during planting seasons, farmers use recycled seeds $[7,8]$. This has stalled production of beans in the country and calls for more breeding efforts to curb the problem.

Development of new varieties requires full participation of stakeholders [9]. On-farm trials have been reported by researchers as vital tools for speeding up of breeding processes and enhanced cultivars adoption rates in farming communities $[10,11]$. On-farm trial enables the incorporation of farmers' opinions and ensures testing of technologies under farmers' management conditions [12]. There are reports of increased rate of adoption and reduced variety abandonment when farmers' knowledge and experiences are acknowledged $[13,14]$. To speed up variety evaluation, testing, and eventually 
TABLE 1: Six testing sites description for three seasons (2003-2006) in Kasulu district, Kigoma region.

\begin{tabular}{|c|c|c|c|c|c|c|c|c|}
\hline Farmer & District & Village & Longitude & Latitude & Altitude (masl) & Max. temp $\left({ }^{\circ} \mathrm{C}\right)$ & Max. temp $\left({ }^{\circ} \mathrm{C}\right)$ & Rainfall (mm) \\
\hline John Bichila & Kasulu & Titye & $03017^{\prime} 281^{\prime \prime} \mathrm{E}$ & $0440^{\prime} 756^{\prime \prime} \mathrm{S}$ & 1148 & 28.70 & 18.70 & 1014.80 \\
\hline Fabian Ntalumanga & Kasulu & Titye & $03017^{\prime} 596^{\prime \prime} \mathrm{E}$ & $0440^{\prime} 185^{\prime \prime} \mathrm{S}$ & 1138 & 29.30 & 19.10 & 1026.60 \\
\hline Selina Dulubaye & Kasulu & Titye & $03017^{\prime} 584^{\prime \prime} \mathrm{E}$ & $0440^{\prime} 163^{\prime \prime} \mathrm{S}$ & 1139 & 29.10 & 18.10 & 1180.90 \\
\hline Geralid Bilaro & Kasulu & Nyenge & $03015^{\prime} 786^{\prime \prime} \mathrm{E}$ & $0437^{\prime} 080^{\prime \prime} \mathrm{S}$ & 1139 & 29.80 & 18.30 & 1025.90 \\
\hline Elias Kapisi & Kasulu & Nyenge & $03015^{\prime} 782^{\prime \prime} \mathrm{E}$ & $0437^{\prime} 096^{\prime \prime} \mathrm{S}$ & 1140 & 29.70 & 18.00 & 1138.20 \\
\hline Margerth Mussa & Kasulu & Nyenge & $03015^{\prime} 783^{\prime \prime} \mathrm{E}$ & $0437^{\prime} 046^{\prime \prime} \mathrm{S}$ & 1145 & 29.60 & 16.00 & 1039.90 \\
\hline Koladi Mussa & Kasulu & Kanazi & $03011^{\prime} 728^{\prime \prime} \mathrm{E}$ & $0431^{\prime} 497^{\prime \prime} \mathrm{S}$ & 1236 & 29.30 & 15.70 & 1204.40 \\
\hline Mohamed Issa & Kasulu & Kanazi & $03013^{\prime} 371^{\prime \prime} \mathrm{E}$ & $0433^{\prime} 981^{\prime \prime} \mathrm{S}$ & 1231 & 30.70 & 16.70 & 1126.40 \\
\hline Japhet Kipara & Kasulu & Kanazi & $03013^{\prime} 423^{\prime \prime} \mathrm{E}$ & $0433^{\prime} 669^{\prime \prime} \mathrm{S}$ & 1257 & 31.30 & 18.90 & 1028.20 \\
\hline
\end{tabular}

TABLE 2: Average yield of beans varieties for three seasons (2003-2006).

\begin{tabular}{lcccc}
\hline Variety & & & Seasons & Mean \\
\hline Lyamungo 90 & $2003 / 2004$ & $2004 / 2005$ & 1469 & 1317 \\
Jesca & 1394 & 1427 & 130.00 \\
Uyole 94 & 1326 & 1334 & 857 & 878 \\
Kablanketi & 880 & 870 & 728 & 908.00 \\
Kigoma yellow & 924 & 924 & 1050 & 714.67 \\
Grand mean & 684 & 732 & 50.3 & 1049.60 \\
SED & 1041 & 1058 & 10.2 \\
CV & 48.2 & 49.2 & & \\
\hline
\end{tabular}

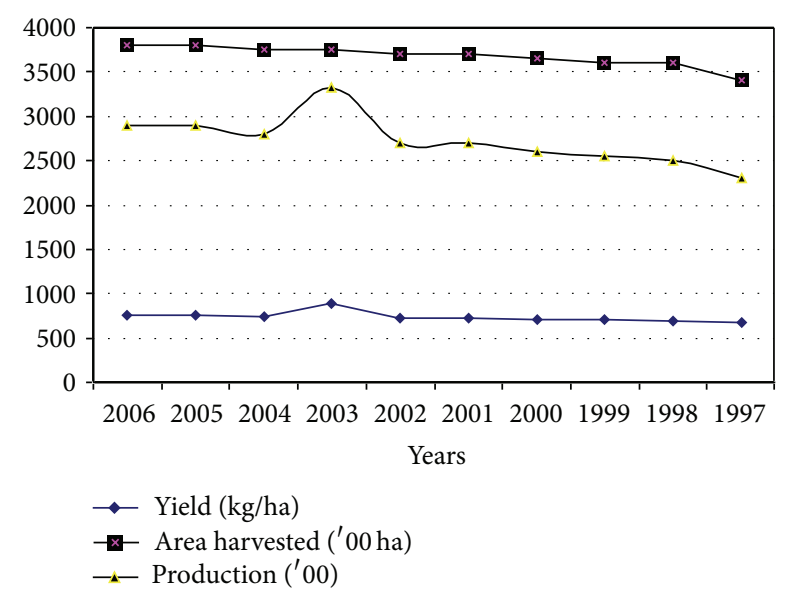

FIGURE 1: Yield of beans and proportion area in Tanzania (19972006). Source: (FAOSTAT, 2008).

introducing new bean varieties to farmers, on-farm bean trials were conducted in Kigoma region, Tanzania. Objectives were to evaluate bean varieties for yield under farmers' management conditions and to assess farmers' preferences on bean varieties.

\section{Materials and Methods}

Common beans on-station trials were conducted in Kigoma region, Tanzania, from 2003 to 2006 seasons. Researchermanaged trials (same managements) were planted in three villages with three farmers per village. Villages included Kanazi, Nyenge, and Titye (Table 1).

A randomized complete block design (RCBD) with five plots per replications was used to evaluate five beans varieties: Lyamungo 90, Jesca, Uyole 94, Kablanketi, and Kigoma yellow (Control). Beans were planted on a $10 \mathrm{~m} \times 2.5 \mathrm{~m}$ plot at a spacing of $50 \mathrm{~cm} \times 20 \mathrm{~cm}$. Data was subjected to analysis using ANOVA table in GenStat statistical computer software. Stability analysis was employed to evaluate varieties sensitivity in different farmers' fields. Three villages $\times$ three seasons resulted in nine environments which were used for stability analysis. To assess farmers, preferences on beans cultivars, participating farmers gathered together and jointly select-ed ten criteria for ranking the cultivars: large seed size, good taste, short cooking time, early maturity, high market demand, high yielding, disease resistance, insect-pest resistance, cooking quality, and suitability to short rainfall farming system (njera season). A scale of 1-5 was used to assess these traits with the definition as follows: $1=$ not preferred, $2=$ less preferred, $3=$ moderately preferred, $4=$ highly preferred, and $5=$ excellent. Farmers were given 5 grains and asked to place $1,2,3,4$, or 5 grains to score a given trait and cultivar. Seeds were counted, and the largest total count was ranked first.

\section{Results}

There were high significant yield differences among varieties across three seasons $(P<0.001)$ with Lyamungo 90 and Jesca outyielding other varieties (Table 2). Lyamungo 90 and Jesca recorded an average yield of 1430.00 and $1325.67 \mathrm{~kg} \mathrm{ha}^{-1}$, 
TABLE 3: AMMI analysis of variances of five bean varieties across nine environments.

\begin{tabular}{|c|c|c|c|c|c|c|}
\hline SOV & DF & SS & MS & $\mathrm{F}$ & F pr & $\mathrm{SS}$ or $\mathrm{GE} \times \mathrm{SS} \%$ \\
\hline Blocks & 18 & 776278 & 43127 & 4.48 & $<0.001$ & 6.65 \\
\hline Genotypes & 4 & 10409365 & 2602341 & 270.17 & $<0.001$ & 89.12 \\
\hline Environment & 8 & 89684 & 11211 & 0.26 & 0.97661 & 0.77 \\
\hline $\mathrm{G} \times \mathrm{E}$ & 32 & 404514 & 12641 & 1.31 & 0.17020 & 3.46 \\
\hline \multicolumn{7}{|l|}{ AMMI model } \\
\hline IPCA1 & 11 & 266533 & 24230 & 2.52 & 0.00969 & 65.89 \\
\hline IPCA2 & 9 & 80958 & 8995 & 0.93 & 0.50149 & 20.01 \\
\hline IPCA3 & 7 & 51734 & 7391 & 0.77 & 0.61648 & 12.79 \\
\hline Residual & 5 & 5289 & 1058 & 0.11 & 0.98983 & 1.31 \\
\hline Total treat & 44 & 10903563 & 247808 & 25.73 & $<0.001$ & \\
\hline Error & 72 & 693518 & 9632 & & & \\
\hline Total & 134 & 2373359 & 92338 & & & \\
\hline
\end{tabular}

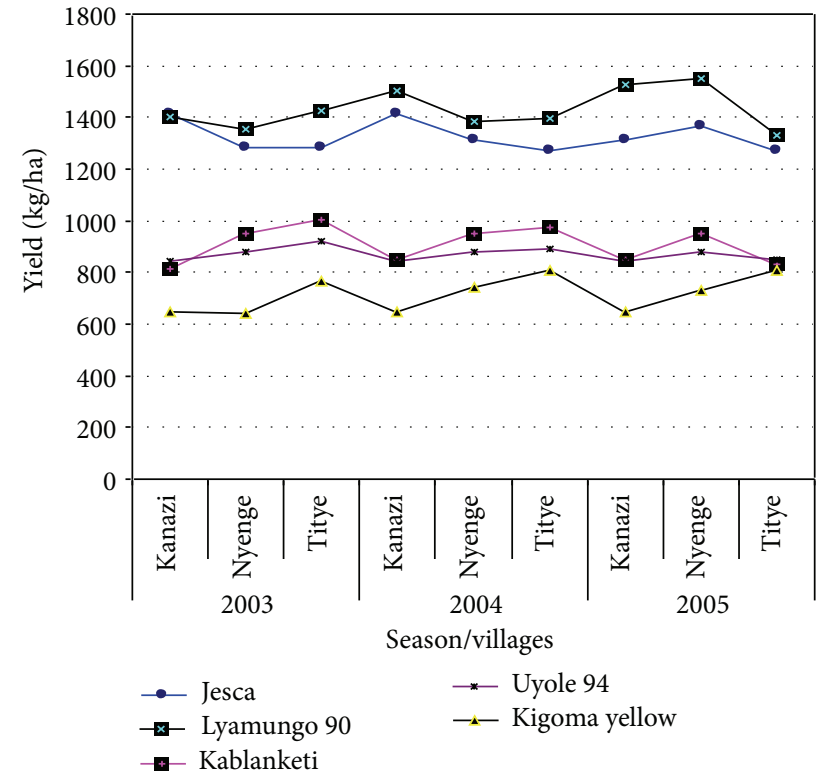

Figure 2: On-farm performance of five bean varieties across three villages for three seasons (2003-2006).

respectively. The overall average yield for all varieties was $1049.60 \mathrm{~kg} \mathrm{ha}^{-1}$.

Results also revealed that the local check (Kigoma yellow) recorded the lowest average yield of $714.67 \mathrm{~kg} \mathrm{ha}^{-1}$.

Figure 2 elaborates the performance of five bean varieties grown in three villages for three seasons. Similar beans yield trends as that of Table 2 were observed.

When additive main effects and multiplicative interactions (AMMI) analysis of five bean varieties across nine environments was performed (Table 3), the IPCA1 was found to be significant. However, IPCA2 and IPCA3 were not significant.

The genotypes sum of squares (SS) accounted for the most of the variability (89.12\%). In addition, results further showed that $\mathrm{G} \times \mathrm{E}$ interactions were superior to environment effects. However, $\mathrm{G} \times \mathrm{E}$ interactions were not significant to denote less importance of its joint effect. Figure 3 elaborates

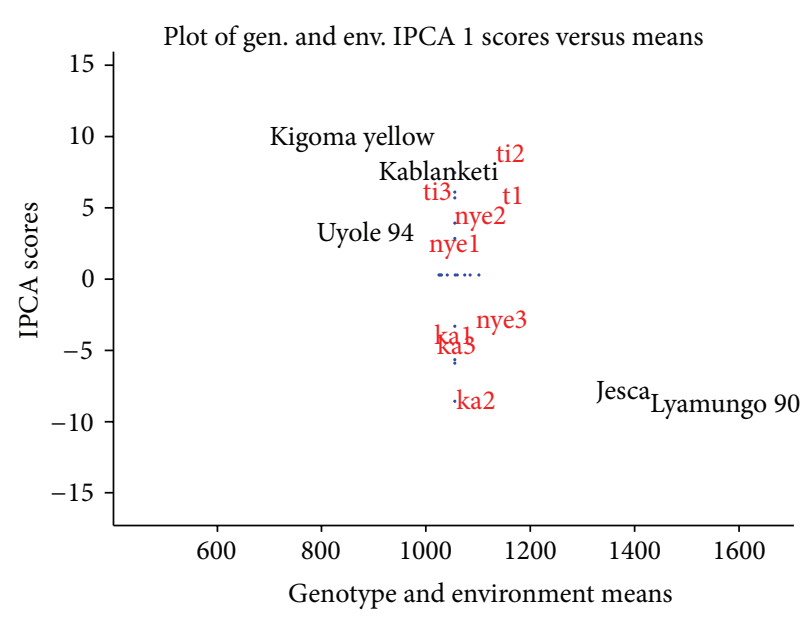

FIGURE 3: IPCA1 scores of five bean varieties, nine environments, and genotype $\times$ environment means. Key: $\mathrm{tl}, 2$, and $3=$ Titye for seasons 1, 2, and 3; kal, 2, and 3 = kanazi for seasons 1, 2, and 3; nye1, 2 , and 3 = Nyenge for season 1,2 , and 3 .

interaction principal component analysis (IPCA) scores against genotypes and environment means.

Figure 3 showed varieties being more dispersed than environments. From this figure, Lyamungo 90 and Jesca bean varieties were allocated on the high yield environments while Kigoma yellow (local check) was on the lower yield environments. Lyamungo 90 and Jesca bean varieties were placed far from zero which is the indication of variety instability. Uyole 94 showed fairly high $\mathrm{G} \times \mathrm{E}$ stability.

Tables 4 and 5 show farmers' assessment on five beans across three seasons.

By using 10 beans traits developed by them, farmers ranked fourth Kigoma yellow (local check) while Lyamungo 90 and Jesca were ranked first and second, respectively. The developed beans traits for assessment were included.

\section{Discussions}

On-farm research on beans revealed significant differences $(P<0.001)$ among varieties with Kigoma yellow recording 
TABLE 4: Farmers on-farm evaluation of five bean varieties for three seasons (2003-2006).

\begin{tabular}{|c|c|c|c|c|}
\hline \multirow{2}{*}{ Variety } & \multicolumn{3}{|c|}{ Seasons } & \multirow{2}{*}{ Ranks } \\
\hline & $2003 / 2004$ & $2004 / 2005$ & $2005 / 2006$ & \\
\hline Lyamungo 90 & 1 & 2 & 1 & 1 \\
\hline Jesca & 2 & 3 & 2 & 2 \\
\hline Uyole 94 & 5 & 3 & 5 & 5 \\
\hline Kablanketi & 3 & 1 & 3 & 3 \\
\hline Kigoma yellow & 4 & 4 & 4 & 4 \\
\hline
\end{tabular}

Key: ranks: 1 = highly preferred, 5 = least preferred.

TABLE 5: Farmers evaluation criteria of five bean varieties at the end of three years project, 2006.

\begin{tabular}{lcccccccccccc}
\hline \multirow{2}{*}{ Variety } & Se & Ta & Co & Ma & Mark & Yield & Disease & Pest & C & S & Total & Rank \\
\hline Lyamu & 4 & 4 & 5 & 4 & 3 & 4 & 4 & 3 & 2 & 3 & 36 & 1 \\
Jesca & 3 & 3 & 4 & 2 & 3 & 5 & 3 & 3 & 5 & 3 & 34 & 2 \\
Uyole & 1 & 1 & 2 & 3 & 2 & 2 & 2 & 2 & 2 & 2 & 19 & 5 \\
Kablan & 5 & 5 & 3 & 2 & 4 & 1 & 2 & 3 & 3 & 2 & 30 & 3 \\
Kigo & 3 & 2 & 3 & 1 & 2 & 1 & 3 & 3 & 3 & 4 & 25 & 4 \\
\hline
\end{tabular}

Key: $\mathrm{Se}=$ large seed size, $\mathrm{Ta}=$ good taste, $\mathrm{Co}=$ short cooking time, $\mathrm{Ma}=$ early maturity, Mark $=$ high market demand, yield $=$ high yielding, disease $=$ disease resistance, pest $=$ insect-pest resistance, $\mathrm{C}=$ cooking quality, and $\mathrm{S}=$ suitability to short rainfall farming system. Varieties: Lyamu $=$ Lyamungo 90 , Jesca, Uyole $=$ Uyole 94, Kablan $=$ Kablanketi, and Kigo $=$ Kigoma yellow .

Scores: 5 = highly preferred, $1=$ least preferred.

the lowest yield. These results clearly indicate the superiority of the introduced varieties over the local variety in the area. The recorded yield was above the national beans yield of $741 \mathrm{~kg} \mathrm{ha}^{-1}[4]$. The observed yield was in accordance to Mekbib [15] who recorded the yield range of $1511-2216 \mathrm{~kg} \mathrm{ha}^{-1}$. The high yielding varieties which were accompanied by farmers' preferences on the new varieties observed in this study suggest the possibility of increased adoption rate in the area. Farmers tend to adopt new technologies that fit their selection criteria [12]. Additionally, high yielding varieties have an added advantage of improving food security and raising farmers' income through reduction of uncertainties and unexpected crop failures provided they are accepted by the community [16].

Farmers' assessment on varieties revealed farmers' power on varieties evaluation and selection. Farmers ranked high Lyamungo 90 and Jesca bean varieties. The reasons given by farmers were high yielding and short cooking time. To improve beans breeding program in Tanzania, these traits are expected to be incorporated in the breeding processes. Statistical analysis ranked the fifth locally adapted variety (Kigoma yellow).

Farmers differed with researchers by ranking it fourth according to their developed criteria. Kigoma yellow was ranked fourth instead of being last because it fits Kigoma farming systems of long and short cropping seasons. It can be planted in both seasons. This variety had adapted Kigoma conditions and thus became suitable for two production seasons. Farmers plant this variety for provision of an added food security to the families [17]. Varieties evaluation and selection which use farmers criteria to meet specific objectives have been reported by other researchers $[18,19]$.
Stability analysis revealed that yield variations were mostly contributed by genotypes (89.12\%). These findings support observations by Jutsum et al. [20]. However, González et al. [21] recorded high environmental variation contribution than genotypes effects. The plot of the interaction principal components analysis against the genotypes and environment means enabled the visual comparison of environments, genotypes, and their interactions. This plot revealed Lyamungo 90 and Jesca as unstable varieties. In addition, these varieties recorded the highest yields across environments. Uyole 94 showed relatively high $\mathrm{G} \times \mathrm{E}$ interaction stability. The reason could be that Uyole 94 was developed at Uyole Agricultural Centre to suite highland environments as that of Kigoma region. Although this variety obtained the lowest rank from farmers' assessment, its stability and yielding relatively high than Kigoma yellow could be a better variety for risk avoidance against production uncertainties $[22,23]$.

\section{Conclusion}

To speed up variety introduction to farmers, on-farm beans experiments were conducted in Kigoma region, Tanzania. Lyamungo 90 and Jesca recorded the highest yield across the environments. Farmers ranked them high which was attributed to high yielding and short cooking time. Introduction of high yielding bean varieties with the desired farmers' traits could revamp beans production and could contribute to the improved food security in the region. Information gathered by this study can be utilized by plant breeders and farmers for incorporation of farmers preferred traits into beans breeding program and bean farming systems. 


\section{References}

[1] T. Dzudie, J. Scher, and J. Hardy, "Common bean flour as an extender in beef sausages," Journal of Food Engineering, vol. 52, no. 2, pp. 143-147, 2002.

[2] B. A. Medvecky, Q. M. Ketterings, and F. M. Vermeylen, "Bean seedling damage by root-feeding grubs (Schizonycha spp.) in Kenya as influenced by planting time, variety, and crop residue management," Applied Soil Ecology, vol. 34, no. 2-3, pp. 240-249, 2006.

[3] A. Krouma, J. J. Drevon, and C. Abdelly, "Genotypic variation of $\mathrm{N}_{2}$-fixing common bean (Phaseolus vulgaris L.) in response to iron deficiency," Journal of Plant Physiology, vol. 163, no. 11, pp. 1094-1100, 2006.

[4] FAO, "Production data," 2008, http://faostat.fao.org/faostat.

[5] P. H. Graham and P. Ranalli, "Common bean (Phaseolus vulgaris L.)," Field Crops Research, vol. 53, no. 1-3, pp. 131-146, 1997.

[6] BACAS, Bureau for Agriculture Consultancy and Advisory Services.: Final Report. Baseline Survey on the Agricultural Research System Under the Department of Research and Training, Volume 1 Western Zone. Synthesis of Main Findings and Recommendations, Sokoine University of Agriculture, Morogoro, Tanzania, 2000.

[7] C. R. Doss, W. Mwangi, H. Verkuijl, and H. deGroote, "Adoption of maize and wheat technologies in eastern Africa: a synthesis of the findings of 22 case studies," Working Paper 03-06, CIMMYT Economics, Sonora, Mexico, 2003.

[8] J. Ouma, H. DeGroote, and M. Gethi, "Focused participatory rural appraisal of farmer's perceptions of maize varieties and production constraints in the moist transitional zone in Eastern Kenya," Economic Working Paper 02-01, CIMMYT and KARI, Nairobi, Kenya, 2002.

[9] J. R. Witcombe, A. Joshi, and S. N. Goyal, "Participatory plant breeding in maize: a case study from Gujarat, India," Euphytica, vol. 130, no. 3, pp. 413-422, 2003.

[10] T. Assefa, G. Abebe, C. Fininsa, B. Tesso, and A.-R. M. AlTawaha, "Participatory bean breeding with women and small holder farmers in eastern Ethiopia," World Journal of Agricultural Sciences, vol. 1, pp. 28-35, 2005.

[11] D. L. Romney, P. Thorne, B. Lukuyu, and P. K. Thornton, "Maize as food and feed in intensive smallholder systems: management options for improved integration in mixed farming systems of east and southern Africa," Field Crops Research, vol. 84, no. 1-2, pp. 159-168, 2003.

[12] C. K. Kaizzi, H. Ssali, and P. L. G. Vlek, "Differential use and benefits of Velvet bean (Mucuna pruriens var. utilis) and $\mathrm{N}$ fertilizers in maize production in contrasting agro-ecological zones of E. Uganda," Agricultural Systems, vol. 88, no. 1, pp. 4460, 2006.

[13] C. M. Moser and C. B. Barrett, "The disappointing adoption dynamics of a yield-increasing, low external-input technology: the case of SRI in Madagascar," Agricultural Systems, vol. 76, no. 3, pp. 1085-1100, 2003.

[14] J. Gressel, A. Hanafi, G. Head et al., "Major heretofore intractable biotic constraints to African food security that may be amenable to novel biotechnological solutions," Crop Protection, vol. 23, no. 8, pp. 661-689, 2004.

[15] F. Mekbib, "Simultaneous selection for high yield and stability in common bean (Phaseolus vulgaris) genotypes," The Journal of Agricultural Science, vol. 138, no. 3, pp. 249-253, 2002.
[16] Z. R. Khan, D. M. Amudavi, C. A. O. Midega, J. M. Wanyama, and J. A. Pickett, "Farmers' perceptions of a 'push-pull' technology for control of cereal stemborers and Striga weed in western Kenya," Crop Protection, vol. 27, no. 6, pp. 976-987, 2008.

[17] R. J. Hillocks, C. S. Madata, R. Chirwa, E. M. Minja, and S. Msolla, "Phaseolus bean improvement in Tanzania, 1959-2005," Euphytica, vol. 150, no. 1-2, pp. 215-231, 2006.

[18] G. Abebe, T. Assefa, H. Harrun, T. Mesfine, and A. M. AlTawaha, "Participatory selection of drought tolerant maize varieties using mother and baby methodology: a case study in the semi arid zones of the central rift valley of Ethiopia," World Journal of Agricultural Sciences, vol. 1, pp. 22-27, 2005.

[19] D. Soleri, S. E. Smith, and D. A. Cleveland, "Evaluating the potential for farmer and plant breeder collaboration: a case study of farmer maize selection in Oaxaca, Mexico," Euphytica, vol. 116, no. 1, pp. 41-57, 2000.

[20] A. R. Jutsum, J. M. Franz, J. W. Deacon et al., "Commercial application of biological control: status and prospects [and discussion]," Philosophical Transactions of the Royal Society of London Series B, Biological Sciences, vol. 318, pp. 357-373, 1988.

[21] A. M. González, A. B. Monteagudo, P. A. Casquero, A. M. de Ron, and M. Santalla, "Genetic variation and environmental effects on agronomical and commercial quality traits in the main European market classes of dry bean," Field Crops Research, vol. 95, no. 2-3, pp. 336-347, 2006.

[22] A. J. McDonald, P. R. Hobbs, and S. J. Riha, "Does the system of rice intensification outperform conventional best management? A synopsis of the empirical record," Field Crops Research, vol. 96, no. 1, pp. 31-36, 2006.

[23] J. D. Reece and J. Sumberg, "More clients, less resources: toward a new conceptual framework for agricultural research in marginal areas," Technovation, vol. 23, no. 5, pp. 409-421, 2003. 


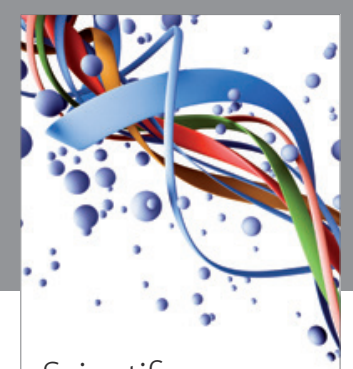

Scientifica
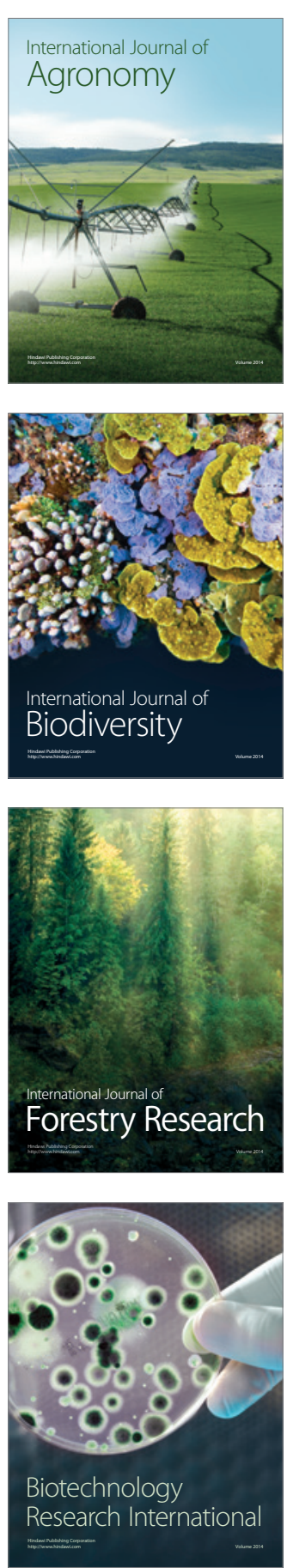
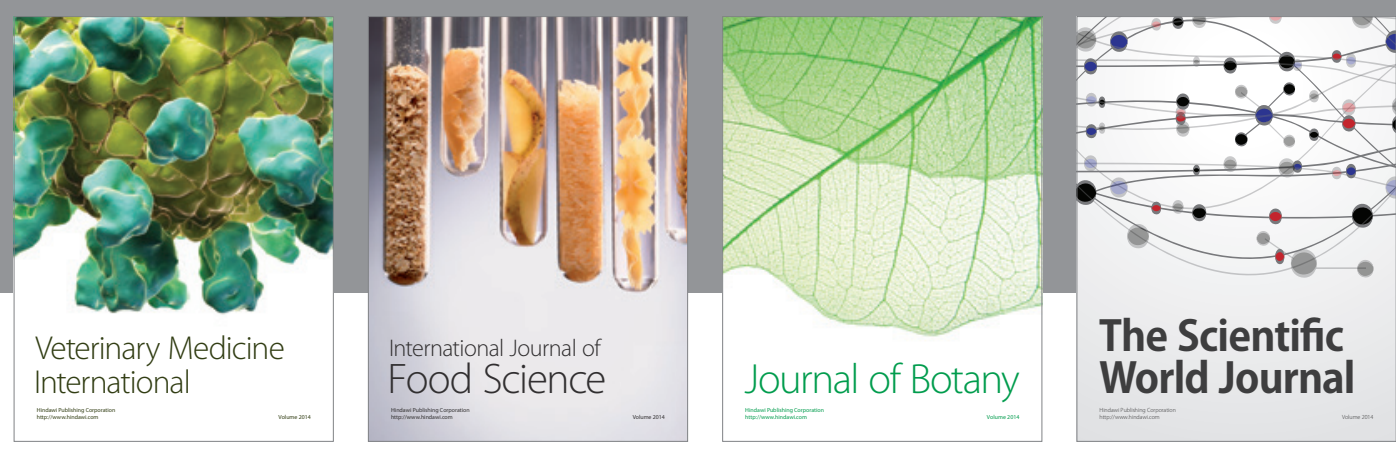

The Scientific World Journal
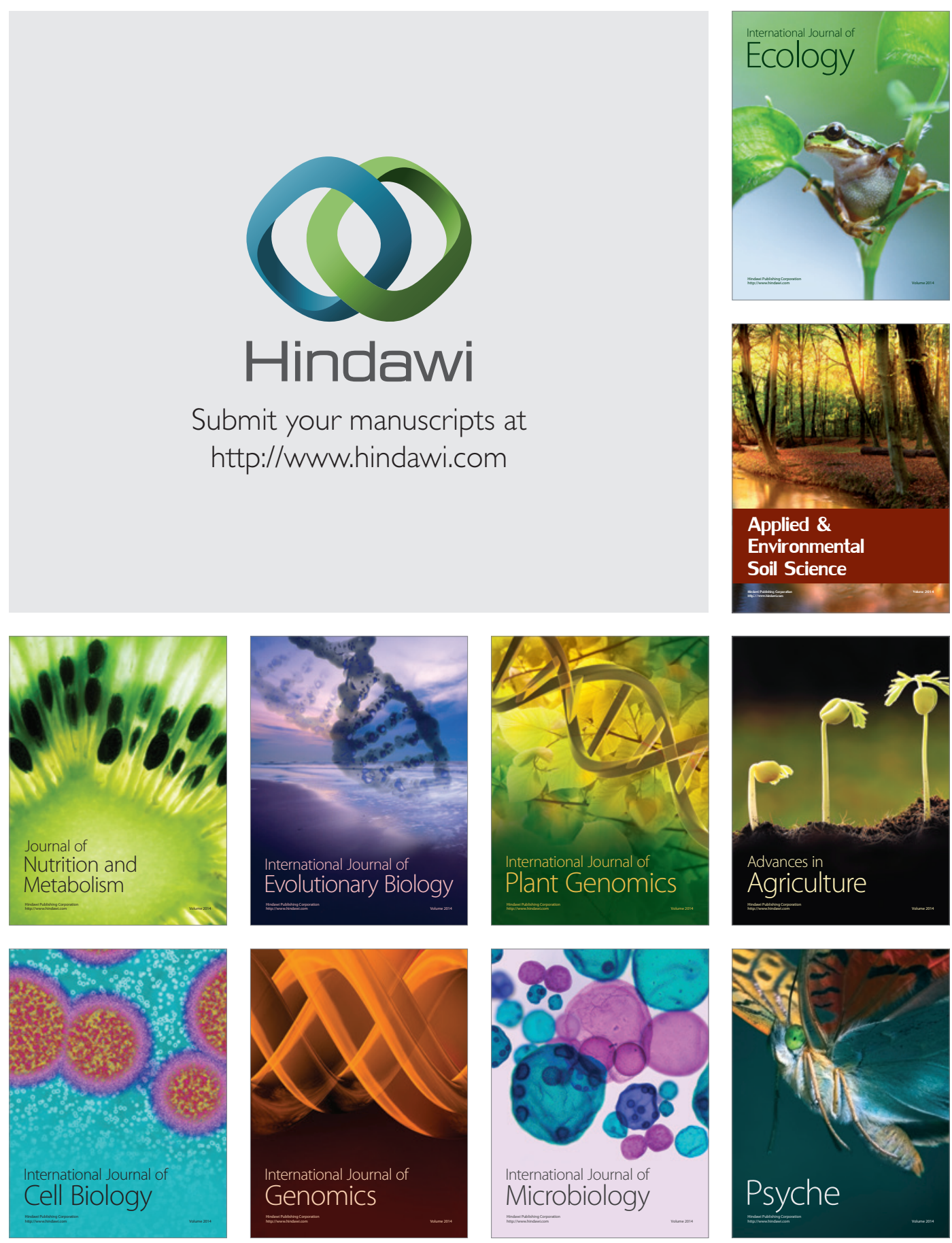